\title{
Griffing's Methods Comparison for General and Specific Combining Ability in Cucumber
}

\author{
J. A. Olfati, ${ }^{1}$ H. Samizadeh, ${ }^{2}$ B. Rabiei, ${ }^{2}$ and Gh. Peyvast ${ }^{1}$ \\ ${ }^{1}$ Department of Horticultural Science, University of Guilan, Rasht 13488-1314, Iran \\ ${ }^{2}$ Department of Agronomy, University of Guilan, Rasht 13488-1314, Iran
}

Correspondence should be addressed to J. A. Olfati, jamalaliolfati@gmail.com

Received 11 October 2011; Accepted 8 December 2011

Academic Editor: Shogo Ozawa

Copyright ( 12012 J. A. Olfati et al. This is an open access article distributed under the Creative Commons Attribution License, which permits unrestricted use, distribution, and reproduction in any medium, provided the original work is properly cited.

\begin{abstract}
A comparison among two forms of half-diallel analysis was made. The different half-diallel techniques used were Griffing's model I, method 2 and 4. These methods of diallel analysis were found to be interrelated. However, as Griffing's model I, method 4 partitioned heterosis into different components as well as gave information about combining ability and this method had certainly some advantages over the other. The results further indicated using parental generations in the second Griffing method may cause biased estimate of the GCA and SCA variances. Thus, using the fourth Griffing method is more suitable than the other methods in providing time, cost, and facilities, and it is recommended as an applicable method.
\end{abstract}

\section{Introduction}

Estimates of combining ability are useful in determining the breeding value of cucumber lines by suggesting the appropriate use in a breeding program. In studying combining ability, the most commonly utilized experimental approach is the diallel design. In the diallel analysis, Sprague and Tatum [1] introduced the concepts of general combining ability (GCA) and specific combining ability (SCA). The GCA is a measure of the additive genic action, while the SCA is assumed to be a deviation from additivity. Crossing a line to several others provides the mean performance of the line in all its crosses. This mean performance, when expressed as a deviation from the mean of all crosses, is called the general combining ability of the line. Any particular cross, then, has an expected value which is the sum of the general combining abilities of its two parental lines. The cross may, however, deviate from this expected value to a greater or lesser extent. This deviation is called the specific combining ability of the two lines in combination. In statistical terms, the general combining abilities are main effects and the specific combining ability is an interaction.

Griffing [2] defines diallel crosses in terms of genotypic values where the sum of general combining abilities for the two gametes is the breeding value of the cross $(i, j)$. Similarly, specific combining ability represents the dominance deviation value in the simplest case ignoring epistatic deviation; see Kempthorne [3] and Mayo [4] for details.

Complete diallel cross designs involve equal numbers of occurrences of each of the distinct crosses among $p$ inbred lines. Gupta and Kageyama [5], Dey and Midha [6], and Das et al. [7] investigated the issue of optimality of complete diallel crosses. When $p$, is large, or reciprocal crosses are similar to direct crosses it becomes impractical to carry out an experiment using a complete diallel cross design. In such situations, we use partial diallel cross designs where a subset of crosses are used. Although efficient designing of partial diallel crosses has been studied by several authors [8-11], no formal optimality result within adequately general classes has been reported except for the recent works of Mukerjee [12] and Das et al. [13]. Sometimes partial diallel crosses can, themselves, be quite large and thus it is desirable to use a block design for the experiment. Gupta et al. [14] and Mukerjee [12] provide orthogonal blocking schemes for partial diallel cross designs.

In the present paper, a comparative view of Griffing's model I, method 2 and 4 has been presented and discussed in light of their practical significance. 
TABLE 1: ANOVA table effect of genotype on yield and some yield components.

\begin{tabular}{|c|c|c|c|c|c|c|c|}
\hline \multirow{2}{*}{$\begin{array}{l}\text { Source of } \\
\text { variation }\end{array}$} & \multirow{2}{*}{$\begin{array}{l}\text { Degree of } \\
\text { freedom }\end{array}$} & \multicolumn{6}{|c|}{ Mean of square } \\
\hline & & Early yield & Marketable yield & $\begin{array}{c}\text { Nonmarketable } \\
\text { yield }\end{array}$ & Total yield & SWI & $\begin{array}{c}\text { Marketable yield } \\
\text { percentage }\end{array}$ \\
\hline Block & 2 & $0.006 \mathrm{~ns}$ & $0.03 \mathrm{~ns}$ & $0.006 \mathrm{~ns}$ & $0.05 \mathrm{~ns}$ & $0.002 \mathrm{~ns}$ & $148.13 \mathrm{~ns}$ \\
\hline Genotype & 20 & $0.06^{* *}$ & $1.31^{* *}$ & $0.01^{* *}$ & $1.39^{* *}$ & $1.52^{* *}$ & $441.26^{* *}$ \\
\hline Error & 40 & 0.01 & 0.07 & 0.003 & 0.06 & 0.08 & 107.84 \\
\hline C.V. $(\%)$ & & 10.71 & 12.73 & 10.51 & 11.15 & 6.51 & 11.91 \\
\hline
\end{tabular}

ns, ** non significant and significant at $P \leq 0.01$ respectively.

TABLE 2: Parent versus hybrids orthogonal comparisons.

\begin{tabular}{lcccccc}
\hline & Early yield & Marketable yield & Nonmarketable yield & Total yield & SWI & Marketable yield percentage \\
\hline Parents & 1.13 & 1.60 & 0.51 & 1.68 & 4.61 & 93.46 \\
Hybrids & 1.03 & 2.31 & 0.58 & 2.49 & 4.37 & 84.65 \\
\hline Orthogonal test & $4.71^{* *}$ & $18.25^{* *}$ & $3.76^{* *}$ & $21.9^{* *}$ & $18.21^{* *}$ & $4.09^{* *}$ \\
\hline
\end{tabular}

** significant at $P \leq 0.01$.

TABLE 3: Mean squares from diallel analysis for various characters in cucumber (Griffing's model I Method 2).

\begin{tabular}{|c|c|c|c|c|c|c|c|}
\hline \multirow{2}{*}{$\begin{array}{l}\text { Source of } \\
\text { variation }\end{array}$} & \multirow{2}{*}{$\begin{array}{l}\text { Degree of } \\
\text { freedom }\end{array}$} & \multicolumn{6}{|c|}{ Mean of square } \\
\hline & & Early yield & Marketable yield & $\begin{array}{c}\text { Nonmarketable } \\
\text { yield }\end{array}$ & Total yield & SWI & $\begin{array}{c}\text { Marketable yield } \\
\text { percentage }\end{array}$ \\
\hline GCA & 5 & $0.13^{* *}$ & $1.15^{* *}$ & $0.026^{* *}$ & $1.580^{* *}$ & $1.37 * *$ & $826.31^{* *}$ \\
\hline SCA & 15 & $0.036^{* *}$ & $1.37^{* *}$ & $0.007^{* *}$ & $1.334^{* *}$ & $1.57^{* *}$ & $340.24^{* *}$ \\
\hline $\mathrm{M}^{\prime} \mathrm{e}$ & 40 & 0.004 & 0.02 & 0.001 & 0.021 & 0.03 & 35.95 \\
\hline $\mathrm{MS}_{\mathrm{GCA}} / \mathrm{MS}_{\mathrm{SCA}}$ & - & $3.61^{*}$ & $0.84 \mathrm{~ns}$ & $3.71^{*}$ & $1.18 \mathrm{~ns}$ & $0.87 \mathrm{~ns}$ & $2.43 \mathrm{~ns}$ \\
\hline Baker ratio & - & 0.878 & 0.63 & 0.881 & 0.703 & 0.64 & 0.33 \\
\hline$h^{2}{ }_{n}$ & - & 0.35 & $\mathrm{~b}$ & 0.31 & 0.04 & $\mathrm{~b}$ & 0.23 \\
\hline
\end{tabular}

ns, ${ }^{*}, * *$ non significant and significant at $P \leq 0.05$ and $P \leq 0.01$ respectively.

b: not estimated because $\mathrm{MS}_{\mathrm{GCA}}<\mathrm{MS}_{\mathrm{SCA}}$.

TABLE 4: Mean squares from diallel analysis for various characters in cucumber (Griffing's model I Method 4).

\begin{tabular}{|c|c|c|c|c|c|c|c|}
\hline \multirow{2}{*}{$\begin{array}{l}\text { Source of } \\
\text { variation }\end{array}$} & \multirow{2}{*}{$\begin{array}{l}\text { Degree of } \\
\text { freedom }\end{array}$} & \multicolumn{6}{|c|}{ Mean of square } \\
\hline & & Early yield & Marketable yield & $\begin{array}{c}\text { Nonmarketable } \\
\text { yield }\end{array}$ & Total yield & SWI & $\begin{array}{c}\text { Marketable yield } \\
\text { percentage }\end{array}$ \\
\hline GCA & 5 & $0.01 \mathrm{~ns}$ & $0.96^{* *}$ & $0.016^{* *}$ & $1.19^{* *}$ & $0.16^{* *}$ & $216.54^{* *}$ \\
\hline SCA & 9 & $0.01 \mathrm{~ns}$ & $1.40^{* *}$ & $0.002 \mathrm{~ns}$ & $1.16^{* *}$ & $1.57^{* *}$ & $393.06^{* *}$ \\
\hline $\mathrm{M}^{\prime} \mathrm{e}$ & 28 & 0.003 & 0.03 & 0.001 & 0.02 & 0.04 & 29.08 \\
\hline $\mathrm{MS}_{\mathrm{GCA}} / \mathrm{MS}_{\mathrm{SCA}}$ & - & $1.00 \mathrm{~ns}$ & $0.69 \mathrm{~ns}$ & $8.00^{* *}$ & $1.03 \mathrm{~ns}$ & $0.10 \mathrm{~ns}$ & $0.55 \mathrm{~ns}$ \\
\hline Baker ratio & - & 0.67 & 0.58 & 0.94 & 0.67 & 0.17 & 0.52 \\
\hline$h^{2}{ }_{n}$ & - & $\mathrm{b}$ & $\mathrm{b}$ & 0.64 & $\mathrm{~b}$ & $\mathrm{~b}$ & $\mathrm{~b}$ \\
\hline
\end{tabular}

ns, ${ }^{*}, * *$ non significant and significant at $P \leq 0.05$ and $P \leq 0.01$ respectively.

b: not estimated because $\mathrm{MS}_{\mathrm{GCA}}<\mathrm{MS}_{\mathrm{SCA}}$.

\section{Matherial and Methods}

To start with, $6 \times 6$ half diallel crosses of cucumber (Cucumis sativus L.) were produced. The varieties used were (1) "BH-502”, (2) “ВH-504”, (3) “ВH-604”, (4) “ВН-605”, (5) "08wvc c-115", (6) "08wvc c-118." These crosses, along with their parents, were evaluated in a randomized block design with three replications. The following characteristics were recorded: early, unmarketable, marketable, and total yield; simple weight index (SWI). Simple weight index was calculated following Wehner and Cramer [15]. The data were analysed using the following models.

\section{Griffing's model I}

(i) Method 2: $X i j=u+g i+g j+s i j+(1 / b) \sum_{k} e_{i j k}$,

(ii) Method 4: $X i j=u+g i+g j+s i j+(1 / b) \sum_{k} e_{i j k}$ 
TABLE 5: High parent heterosis and mid parent heterosis for early yield and marketable yield.

\begin{tabular}{|c|c|c|c|c|c|}
\hline \multirow{2}{*}{ Female Parent } & \multirow{2}{*}{ Male parent } & \multicolumn{2}{|c|}{ Early yield } & \multicolumn{2}{|c|}{ Marketable yield } \\
\hline & & Mid parent heterosis & High parent heterosis & Mid parent heterosis & High parent heterosis \\
\hline 604 & 605 & 0.00 & 0.00 & 0.28 & 0.08 \\
\hline 604 & 504 & 0.00 & 0.00 & 0.89 & 0.61 \\
\hline 604 & 118 & 0.00 & 0.00 & 0.53 & 0.47 \\
\hline 604 & 502 & -0.07 & -0.14 & -0.06 & -0.43 \\
\hline 604 & 115 & -0.31 & -0.62 & 1.33 & 1.25 \\
\hline 605 & 504 & 0.00 & 0.00 & 0.50 & 0.01 \\
\hline 605 & 118 & 0.00 & 0.00 & 0.73 & 0.47 \\
\hline 605 & 502 & -0.07 & -0.14 & 0.42 & -0.15 \\
\hline 605 & 115 & -0.31 & -0.62 & 1.53 & 1.24 \\
\hline 504 & 118 & 0.00 & 0.00 & 1.30 & 1.07 \\
\hline 504 & 502 & -0.07 & -0.14 & -0.16 & -0.24 \\
\hline 504 & 115 & -0.17 & -0.49 & 1.36 & 1.16 \\
\hline 118 & 502 & 0.07 & 0.00 & 1.00 & 0.69 \\
\hline 118 & 115 & -0.31 & -0.62 & -0.41 & -0.44 \\
\hline 502 & 115 & -0.24 & -0.49 & 1.30 & 1.02 \\
\hline
\end{tabular}

TABLE 6: High parent heterosis and mid parent heterosis for nonmarketable yield and total yield.

\begin{tabular}{|c|c|c|c|c|c|}
\hline \multirow{2}{*}{ Female Parent } & \multirow{2}{*}{ Male parent } & \multicolumn{2}{|c|}{ Nonmarketable yield } & \multicolumn{2}{|c|}{ Total yield } \\
\hline & & Mid parent heterosis & High parent heterosis & Mid parent heterosis & High parent heterosis \\
\hline 604 & 605 & 0.04 & 0.04 & 0.418 & 0.213 \\
\hline 604 & 504 & 0.12 & 0.12 & 1.077 & 0.793 \\
\hline 604 & 118 & 0.08 & 0.08 & 0.697 & 0.643 \\
\hline 604 & 502 & 0.12 & 0.12 & 0.215 & -0.150 \\
\hline 604 & 115 & 0.08 & 0.00 & 1.330 & 1.020 \\
\hline 605 & 504 & 0.08 & 0.08 & 0.672 & 0.183 \\
\hline 605 & 118 & 0.04 & 0.04 & 0.822 & 0.563 \\
\hline 605 & 502 & 0.04 & 0.04 & 0.510 & -0.060 \\
\hline 605 & 115 & 0.11 & 0.03 & 1.588 & 1.073 \\
\hline 504 & 118 & 0.04 & 0.04 & 1.357 & 1.127 \\
\hline 504 & 502 & 0.11 & 0.11 & 0.068 & -0.013 \\
\hline 504 & 115 & 0.08 & 0.00 & 1.337 & 1.310 \\
\hline 118 & 502 & 0.07 & 0.07 & 1.115 & 0.803 \\
\hline 118 & 115 & 0.04 & -0.03 & -0.257 & -0.513 \\
\hline 502 & 115 & 0.08 & 0.00 & 1.278 & 1.223 \\
\hline
\end{tabular}

$(i=j=1 \ldots p ; k=1 \ldots b)$, where $u=$ the population mean; $g i=$ the general combining ability effect of the $i$ th parent; $g j=$ the general combining ability effect of the $j$ th parent; $i j=$ the specific combining ability effect of the cross between $i$ th and $j$ th parents such that $s l j=s j i$; $e i j k=$ the environmental effect associated with $i j k$ th observation.

\section{Results and Discussions}

The analysis of variance for all measured traits carried out for testing the significance of genotypic differences is given in
Table 1. The genotypic variance was also partitioned into its appropriate orthogonal components, namely, parents versus hybrids (Table 2). The genotypic differences were found significant. Significant differences were observed among the parents and hybrids. However, the significant differences of mean square associated with parents versus hybrids indicated availability of average heterosis for all traits. In Griffing's method 2, the variances due to gca and sca effects were highly significant for all traits (Table 3). However, the variance of early yield due to gca affects was not significant in method 4 . On the other hand, the variance of early and nonmarketable yield due to sca effects was not significant (Table 4). The baker ratio in method 2 indicated the predominant role of 
TABLE 7: High parent heterosis and mid parent heterosis for SWI and marketable yield percentage.

\begin{tabular}{lccccc}
\hline \multirow{2}{*}{ Female Parent } & \multirow{2}{*}{ Male parent } & \multicolumn{2}{c}{ SWI } & \multicolumn{2}{c}{ Marketable yield percentage } \\
& & Mid parent heterosis & High parent heterosis & Mid parent heterosis & High parent heterosis \\
\hline 604 & 605 & -0.72 & -0.77 & 0.00 & 0.00 \\
604 & 504 & -0.90 & -1.00 & -13.10 & -13.10 \\
604 & 118 & -0.55 & -0.57 & -15.00 & -15.00 \\
604 & 502 & -1.36 & -1.50 & -26.11 & -26.11 \\
604 & 115 & 0.91 & -0.25 & 5.46 & -14.17 \\
605 & 504 & -0.78 & -0.93 & -15.00 & -15.00 \\
605 & 118 & -0.30 & -0.37 & -8.33 & -8.33 \\
605 & 502 & -0.42 & -0.61 & -8.33 & -1.90 \\
605 & 115 & 0.82 & -0.29 & -3.03 & -17.73 \\
504 & 118 & 0.49 & 0.41 & -17.86 & -17.86 \\
504 & 502 & -1.53 & -1.57 & 7.99 & -11.64 \\
504 & 115 & 0.87 & -0.39 & -7.41 & -4.41 \\
118 & 502 & -0.62 & -0.75 & -24.81 & -14.44 \\
118 & 115 & -0.71 & -1.89 & -0.16 & \\
502 & 115 & 1.13 & & & -11.49 \\
\hline
\end{tabular}

additive type of gene effects for early yield, nonmarketable yield, and total yield while in method 4 , this ratio indicated the predominant role of additive type of gene effects only for nonmarketable yield.

Heterosis tables showed that there are high heterosis for traits that show high SCA in method 4 Griffings (marketable yield, total yield, SWI, marketable yield percentage). In fact, this result indicated that method 4 is more suitable than method 2. Some authors believe that when the differences between hybrids and parents are significant, method 4 without parents entering in estimations is better that method 2 [16]. They in comparison of the second and fourth Griffing methods showed that the proportions of additive and nonadditive variances in two methods were different. Therefore, it could be concluded that using parental generations in the second Griffing method may cause biased estimate of the GCA and SCA variances [2]. Thus, using the fourth Griffing method is more suitable than the other methods in providing time, cost, and facilities, and it is recommended as an applicable method (Tables 5, 6, and 7).

\section{References}

[1] G. F. Sprague and L. A. Tatum, "General vs specific combining ability in single crosses of corn," Journal of the American Oil Chemists Society, vol. 34, pp. 923-932, 1942.

[2] B. Griffing, "Concept of general and specific combining ability in relation to diallel crossing systems," Australian Journal of Biological Sciences, vol. 9, pp. 463-493, 1956.

[3] O. Kempthorne, An Introduction to Genetic Statistic, Iowa State University Press, Ames, Iowa, USA, 1969.

[4] O. Mayo, The Theory of Plant Breeding, Clarendon Press, Oxford, UK, 1980.

[5] S. Gupta and S. Kageyama, "Optimal complete diallel crosses," Biometrika, vol. 81, no. 2, pp. 420-424, 1994.

[6] A. Dey and C. K. Midha, "Optimal block designs for diallel crosses," Biometrika, vol. 83, no. 2, pp. 484-489, 1996.
[7] A. Das, A. Dey, and A. M. Dean, "Optimal block designs for diallel cross experiments," Statistics \& Probability Letters, vol. 36, pp. 427-436, 1998.

[8] A. S. Arya, "Circulant plans for partial diallel crosses," Biometrics, vol. 39, no. 1, pp. 43-52, 1983.

[9] K. Hinkelmann and O. Kempthorne, "Two classes of group divisible partial diallel crosses," Biometrika, vol. 50, pp. 281291, 1963.

[10] M. Singh and K. Hinkelmann, "On generation of efficient partial diallel crosses," Biometrical Journal, vol. 32, pp. 177187, 1990.

[11] M. Singh and K. Hinkelmann, "Partial diallel crosses in incomplete blocks," Biometrics, vol. 51, no. 4, pp. 1302-1314, 1995.

[12] R. Mukerjee, "Optimal partial diallel crosses," Biometrika, vol. 84, no. 4, pp. 939-948, 1997.

[13] A. Das, A. M. Dean, and S. Gupta, "On optimality of some partial diallel cross designs," Sankhya, vol. 60, pp. 511-524, 1998.

[14] S. Gupta, A. Das, and S. Kageyama, "Single replicate orthogonal block designs for circulant partial diallel crosses," Communications in Statistics - Theory and Methods, vol. 24, pp. 26012607, 1995.

[15] T. C. Wehner and C. S. Cramer, "Ten cycles of recurrent selection for fruit yield, earliness, and quality in three slicing cucumber populations," Journal of the American Society for Horticultural Science, vol. 121, no. 3, pp. 362-366, 1996.

[16] M. Rahimi, B. Rabiei, H. Samizadeh-Lahiji, and A. KafiGhasemi, "Evaluation of combining ability in rice cultivars based on second and fourth griffing methods," Journal of Science and Technology of Agriculture and Natural Resources, vol. 12, no. 43, pp. 129-141, 2008. 


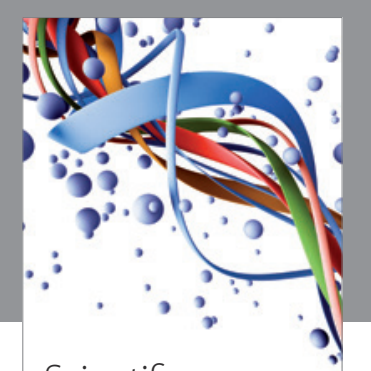

Scientifica
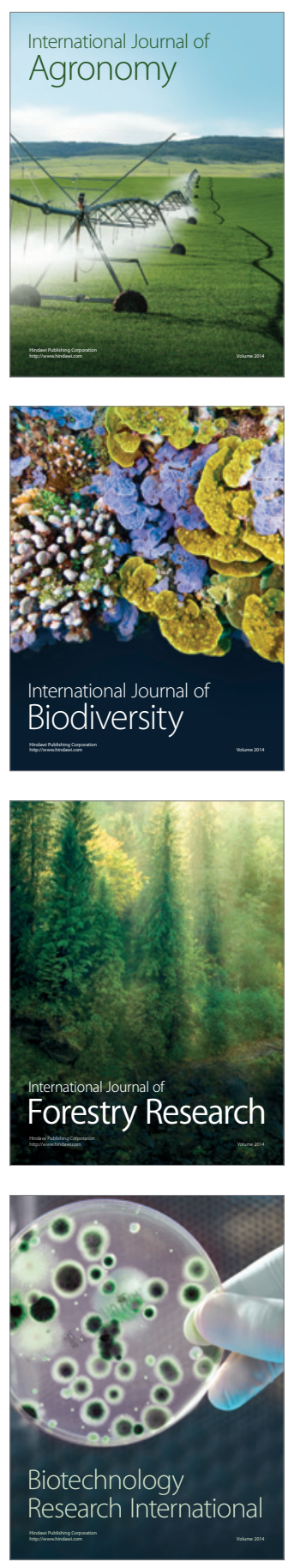
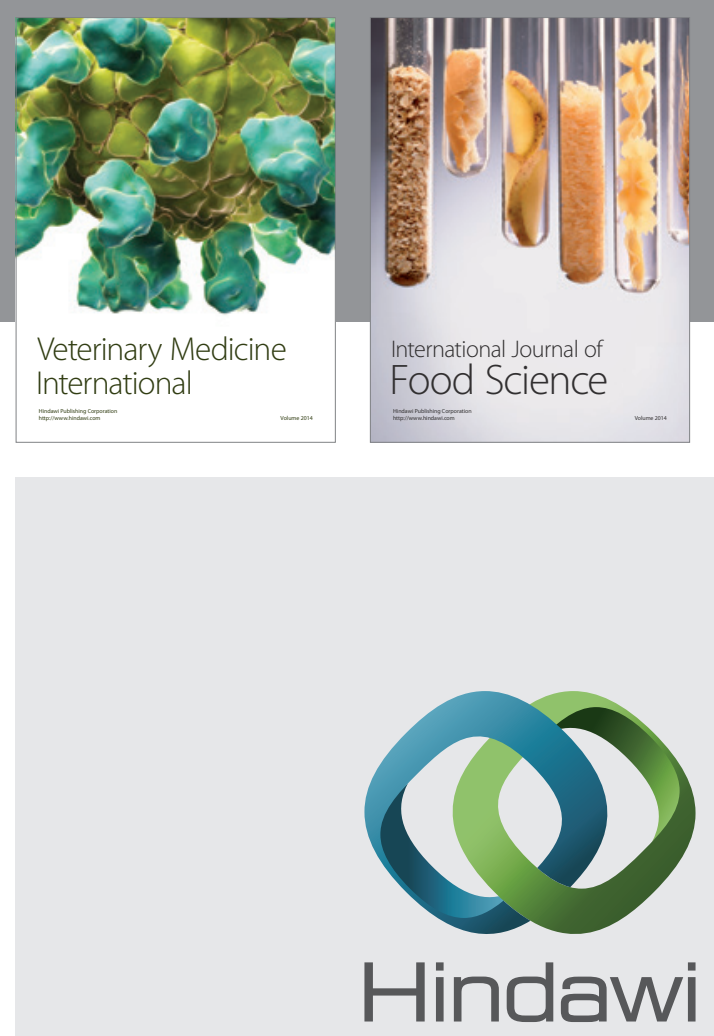

Submit your manuscripts at

http://www.hindawi.com
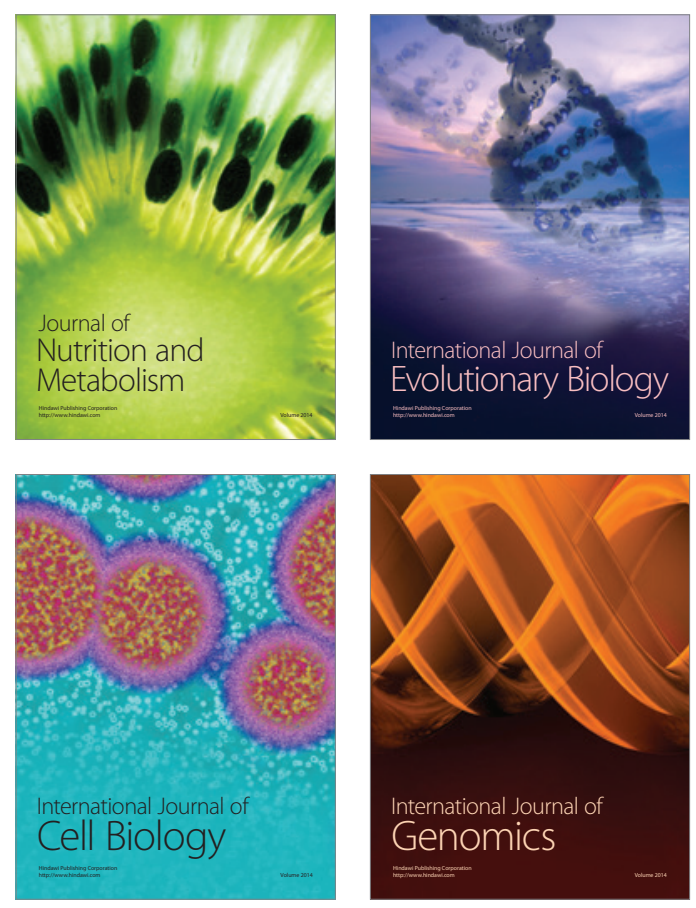
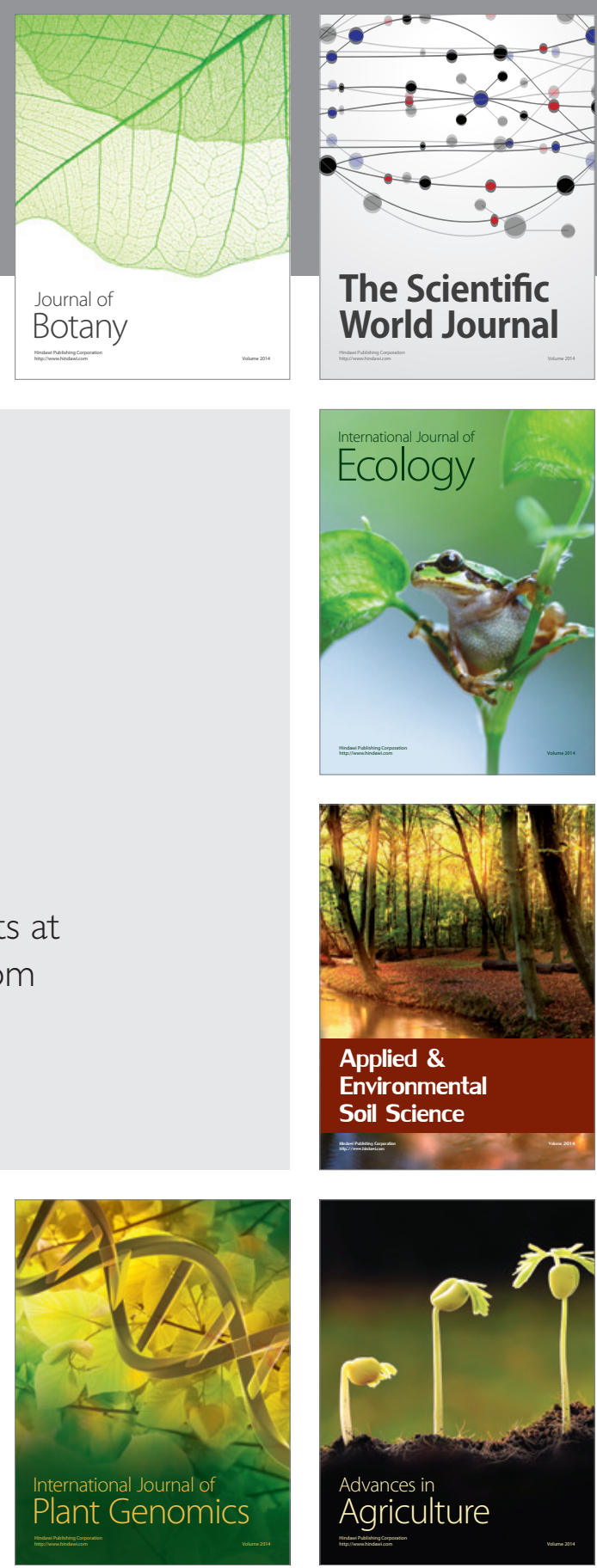

The Scientific World Journal
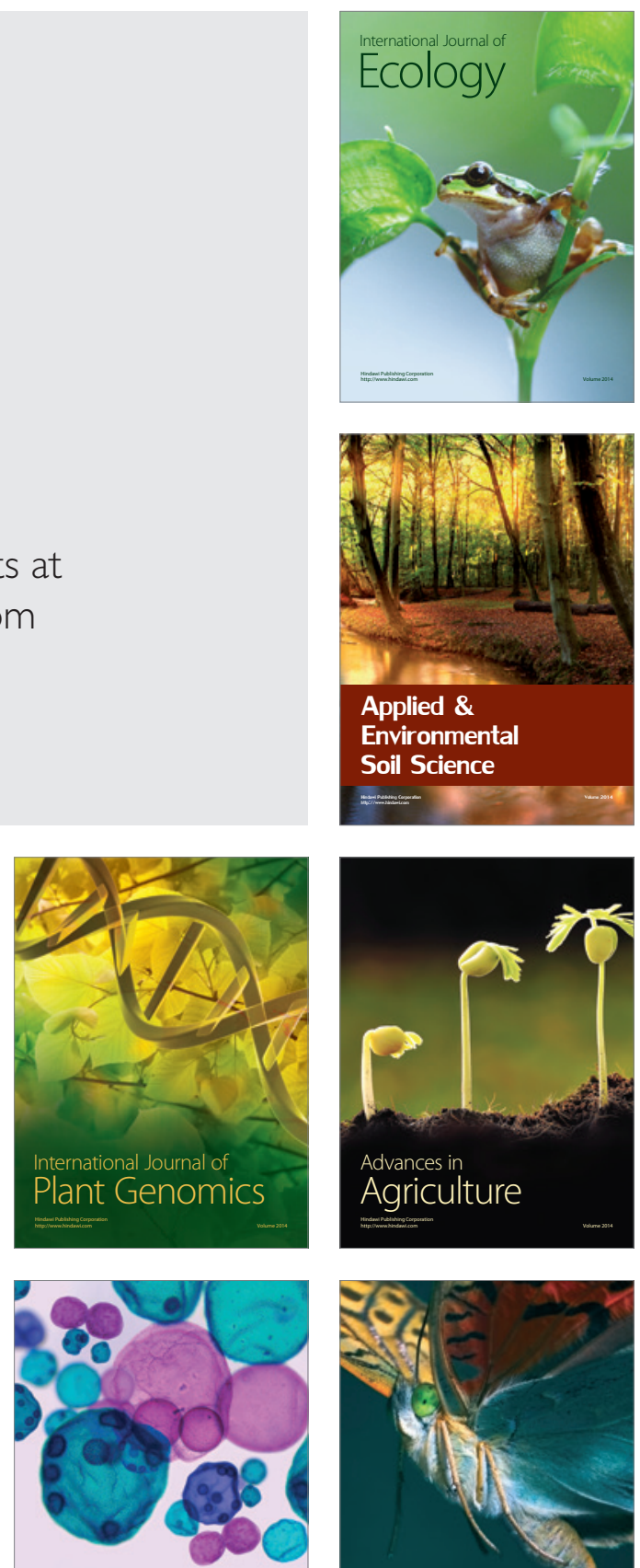

International Journal of Microbiology

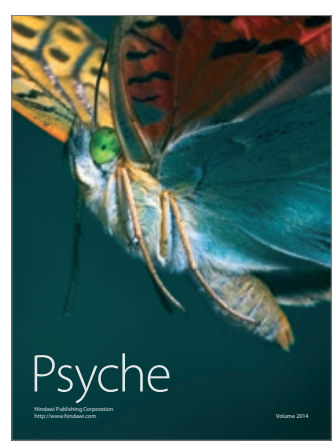

